Vol. 52, no. 1 (2014), pp. 59-83, doi: 10.14421/ajis.2014.521.59-83

\title{
BEING WOMAN IN THE LAND OF SHARI'A Politics of the Female Body, Piety and Resistance in Langsa, Aceh ${ }^{1}$
}

\author{
Muhammad Ansor \\ State College for Islamic Studies (STAIN) Zawiyah Cot Kala, Langsa, \\ Indonesia \\ email:ansor_riau@yahoo.co.id
}

\begin{abstract}
This study investigates the dynamic of institutionalization of Shari'a in Aceh, which focuses on analysis of the patterns of Langsa women's resistance against religious leaders and state interpretations of the dress standards in the public space. This matter emerged because the implementation of Shari'a has been supported by local people, but the standard of Islamic dress that should be applied is still debatable among various groups in Aceh that have varied understandings and different religious visions. The regulation of dress code has been an issue for religious leaders, intellectuals, and Moslem activists. The resistance of Langsa women against the politics of body discipline could be open and secret. To analyze the forms of women's resistance, the researcher applied James C. Scott's hidden transcripts theory. Inspired by this theoretical framework, the researcher found that Langsa women, intellectuals, and religious leaders expressed their resistance over how women should dress in public space. In collecting the data, the researcher used observation, in-depth

${ }^{1}$ This paper is a revised and translated version of an article entitled Pakaian Ketat di Negeri Syariat: Politik. Tubuh, Kesalehan dan Resistensi Perempuan Langsa that was presented at the AICIS (Annual International Conference of Islamics Studies) XIII, held in Mataram, November 18-21, 2013. I would like thank Irwan Abdullah and Zainal Abidin Baqir (Gadjah Mada University) for their advice during the research process. Thank to Jesse Hession Grayman (Nanyang Technological University) for insightful comments and editing my english. My thanks go also to my friends at CRCS (Center for Religious and Cross-Cultural Studies) UGM and the anonymous readers for contributing ideas that enriched the research perspective.
\end{abstract}


interviews, and focus group discussions. Accordingly, the research shows how Langsa women express their resistance towards religious hegemony and state interpretation of Islam.

Tulisan ini membahas dinamika pelembagaan syariat Islam di Aceh dengan fokus resistensi tersembunyi perempuan Langsa terhadap penafsiran elite agama dan pemerintah perihal pembakuan standar pakaian di ruang publik. Meskipun implementasi syariat Islam Aceh mendapat dukungan masyarakat setempat, tetapi ketika sebuah tafsir tertentu tentang pakaian Islami dibakukan dalam regulasi (Qanun), munculperdebatan dari sebagian muslim yang berpola pemikiran dan visi keagamaan berbeda. Bukan hanya perdebatan di kalangan elite agama, intelektual, maupun aktivis, perempuan di berbagai daerah di Aceh pun mengekspresikan resistensi, baik secara terbuka maupun tersembunyi. Peneliti menggunakan teori bidden transcripts sebagaimana dikemukakan James C. Scott untuk menganalisa resistensi tersebut. Data dikumpulkean melalui observasi, wawancara mendalam, serta diskusi kelompok terfokus (FGD). Penelitian ini memperlihatkan bagaimana perempuan Langsa mengekspresikan resistensi tersembunyi atas hegemoni elite agama dan pemerintah dalam menafsirkan Islam].

Keywords: hidden transcripts, Acehnese women, politics of female body, sharia regulation.

\section{A. Introduction}

For most visitors, perhaps there is nothing special about the phenomenon that occurs daily at the right gate of Darul Falah, herein called Grand Mosque in Langsa. To me, however, this phenomenon is very interesting and warrants discussion. In August 2012 after prayer congregation, I noticed a number of young women wearing leggings and covering their lower bodies with a sarong entering the area of the Grand Mosque. As they left the Mosque after praying, the same women caught my attention taking off their sarongs at the gate as they first stepped into the outer area of the Grand Mosque. Their expression was one of relief from burden, as if they had been freed from jail. Other women might take off their sarong when they arrive at home or at the stores where they work around the Grand Mosque. The phenomenon reflected one of the ways that women resist the announcement on the noticeboard at the gate to the Grand Mosque: "Kawasan Wajib Berbusana Islami, Dilarang 
Memakai Pakaian Ketat (Mandatory Islamic dress area, the wearing of tight clothing is forbidden).

The most controversial aspect in the implementation of shari'a in Aceh has been the introduction of the Islamic dress code (Wajib Berbusana Islami) in 2002, particularly the forced veiling of Muslim women. Qanun No 2/2002 on the implementation of Islamic law in the areas of worship and dissemination of Islamic teachings has been invoked to punish those who do not wear headscarves in public and do not follow the prescribed norm of decency in attire. ${ }^{2}$

However, the implementation of sharia in Aceh, especially the women's dress code sparked varied responses. This is seen in the survey I conducted on religious behavior in Langsa. Based on this study, it was reported that 66.1 percent of the 305 respondents interviewed said that women should wear the veil and dress in loose clothing; 12.1 percent said that they allow the tight dress for women as long as she wears the veil; and 12.2 percent of respondents said that women are free to determine their own style whether they desire to wear a veil or not. However, 80 percent of respondents agreed with the action of razia jilbab conducted by the Shari'a Police. ${ }^{3}$ The data show that despite the majority of respondents in Langsa approving of the regulation on women's dress, the resistant group was quantitatively quite significant.

This paper explores Langsa women's resistance against the disciplinary code in relation to the female body and dress in the name of Islamic law. I also analyze the strategies of women's resistance against the regulation. The research was conducted in Langsa through observation and interviews. Observations were focused at State Colleges for Islamic Studies (STAIN, Sekolah Tinggi Agama Islam Negeri) Zawiyah Cot Kala, the Grand Mosque, Merdeka Square, and Langsa's Ring Road. These were common places where the people with divergent views on female body discipline could be found and interviewed. I interviewed the head of DSI (Department of Islamic Law) Langsa, members of the WH (Wilayatul Hisbah, Shari'a Police), Moslem intellectuals, Islamics scholars or ulama and some women. I interviewed women coming from various backgrounds, listening to their gossip about topics relevant to

${ }^{2}$ Ma. Theresa R. Milallos, "Muslim Veil as Politics: Political Autonomy, Women and Syariah Islam in Aceh", Contemporary Islam: Dynamics of Muslim Life, vol. 1, no. 3 (2007), p. 297.

${ }^{3}$ Muhammad Ansor, Muhammad Abu Bakar, and Zubir, Religiusitas dan Sikap atas Pelaksanaan Syariat Islam di Langsa, Research (Aceh: STAIN Zawiyah, 2010), p. 126. Al-Jāmi'ah, Vol. 52, No. 1, 2014 M/1435 H 
the research, and held discussions with women activists and students resistant to the regulation and disciplining of women's bodies. ${ }^{4}$

This paper applies James C. Scott's hidden transcripts theory to analyze Langsa women's resistance to dress regulations. According to Scott, relations of domination are relations of resistance. ${ }^{5}$ Scott defines resistance as any action taken by the subordinate group that is intended to mitigate or deny claims made on that class by superordinate classes vis-a-vis these superordinate classes. ${ }^{6}$ It provides us with a diagnostic of everyday resistance involving no protest or organization as is commonly understood. $^{7}$

Scott divides the opposition into two parts, namely public transcripts and hidden transcripts. According to Scott, the distinction between the hidden and the public transcripts, together with the hegemonic aspiration of the public transcripts allow us to distinguish at least four varieties of political discourse among subordinate groups. ${ }^{8}$ Public transcripts include resistance that (1) is organic, systematic, and cooperative, (2) is principled or selfless, (3) has revolutionary consequences, and/or (4) negates dominance bases. ${ }^{9}$ In contrast, hidden transcripts are characterized as (1) irregular, not systematic and occur individually, (2) opportunistic and self-serving, (3) without revolutionary consequences, and/or (4) more accommodating to the system of domination. ${ }^{10}$

In this research, the enforcement of the women's body discipline

${ }^{4}$ Respondents knew my capacity as a researcher who will publish the information. I recorded the interviews only if approved by research participants. However, their names have been changed to protect their identities. The names of public officials in Langsa have not been disguised as their names are already publicly known, at least in Langsa.

${ }^{5}$ James C. Scott, Domination and the Arts of Resistance: Hidden Transcripts (London: Yale University Press, 1990), p. 45.

${ }^{6}$ James C. Scott, "Resistance without Protest and without Organization: Peasant Opposition to the Islamic Zakat and the Christian Tithe", Comparative Studies in Society and History, vol. 29, no. 03 (1987), p. 419; James C. Scott, Senjatanya Orang-orang yang Kalah: Bentuk-bentuk Perlawanan Sehari-hari Kaum Tani, trans. by A. Rahman Zainuddin, Sayogyo, and Mien Joebhaar (Yayasan Obor Indonesia, 2000), p. 383.

${ }^{7}$ Scott, "Resistance without Protest and without Organization: Peasant Opposition to the Islamic Zakat and the Christian Tithe”, p. 424.

${ }^{8}$ Scott, Domination and the Arts of Resistance, p. 18.

${ }^{9}$ Ibid., p. 385.

${ }^{10}$ Ibid., pp. 385-386. For Scott, hidden resistance has same consequences with open resistance. Perhaps, hidden resistance is individual but it has effect to a lot of people. But, it is still different from the open resistance mode, either in relation to the pattern and its consequences. 
code through dominant power tends to ignite resistance. ${ }^{11}$ Padma Anagol defines women's resistance as a conscious act, characterized by intention arising within conditions of unequal power relations within society, and often generated by imbalances of power between the sexes. ${ }^{12}$

As mentioned above, this study focuses on the hidden resistance rather than open resistance because hidden transcripts are more common in Langsa than public transcripts. ${ }^{13}$ In general, various expressions of protest among women against this regulation have arisen, for example, putting on tight clothing despite being aware of the regulations that prohibit it, reinterpreting religious texts about Islamic dress, and sneering and looking down upon the $\mathrm{WH}$ assigned to conduct the razia. The scenerio of woman who wear tight clothes in Langsa is beyond tolerable limits of the regulations, indicating that it is not unusual, rather an expression of protest against the enforcement of a hegemonic interpretation of how to dress in Islam.

\section{B. Instruments of Discipline of Women's Bodies}

Many Acehnese, especially headmasters of Islamics boarding schools (ulama dayah), and Islamics scholars affiliated with DSI and MPU (Majelis Permusyawaratan Ulama, Ulama Consultative Assembly) ${ }^{14}$ believe that the implementation of Shari'a through a state approach is more effective than through a cultural approach. ${ }^{15}$ It is characterized by the issuance of Qanun No. 11/2002, which regulates Islamic dress and bans

${ }^{11}$ Ketu H. Katrak, Politics of the Female Body: Postcolonial Women Writers of the Third World (Rutgers University Press, 2006), p. 3.

${ }^{12}$ Padma Anagol, "From the Symbolic to the Open: Women's Resistance in Colonial Maharashtra", in Bebind the Veil: Resistance, Women, and the Everyday in Colonial South Asia, ed. by Ghosh Anindita (Permanent Black, 2007), p. 27.

${ }^{13}$ The recent studies on some forms of cultural resistance to Shari'a in Acehnese society, particularly in Banda Aceh, see: Reza Idria, Cultural Resistance to Shariatism in Aceh, Final (Jakarta: Islam Research Programm, 2013), pp. 180-201, http:/ / media.leidenuniv. nl/legacy/irpfinal2013(2).pdf.

${ }^{14}$ The MPU was recast as Aceh's branch of the Indonesian Ulama Council (Majelis Ulama Indonesia, MUI) in the 1970s, but in the reformasi era, once again became known as the MPU; see: Shane Joshua Barter, "Ulama, the State, \& War: Community Islamic Leaders in the Aceh Conflict", Contemporary Islam: Dynamics of Muslim Life, vol. 5, no. 1 (2011), p. 27.

${ }^{15}$ Arskal Salim, Challenging the Secular State: The Islamization of Law in Modern Indonesia (University of Hawaii Press, 2008), p. 134. 
tight clothing. ${ }^{16}$ The Qanun of Shari'a occupies the highest rank on the list of disciplinary instruments for women's bodies through a state approach. ${ }^{17}$ Although the formulation of the Qanun is general, it is difficult to deny that the targets are mostly women.

The Qanun says, for example:

- Setiap orang wajib berbusana Islami. Busana Islami adalah pakaian yang menutup aurat yang tidak tembus pandang, dan tidak memperlihatkan bentuk tubuh [Everybody is obliged to wear Islamic dress. Islamic dress is clothes that covers naked flesh and does not show the shape of bodies].

- Pimpinan instansi pemerintah, lembaga pendidikan, badan usaha atau institusi masyarakat wajib membudayakan busana Islami dilingkungannya. Wajib membudayakan busana Islami maksudnya bertanggung-jawab terhadap pemakaian busana Islami oleh pegawai, anak didik atau karyawan (karyawati) di lingkungan masing-masing, termasuk pada saat kegiatan olahraga [Heads of government offices, educational institutions, and corporate or social organization are obliged to promote Islamic dress in their environments, whereby the officers, students, or employees are obliged to abide by the Islamic dress code, including at sports events]. ${ }^{18}$

${ }^{16}$ However, in terms of actual enforcement the most important Acehnese Qanun have been the laws passed in 2003: No. 12 on consumption of alcohol, No. 13 on gambling, and No. 14 on khalwat "improper covert association" between members of the opposite sex). Other laws along these lines include Qanun Propinsi Nanggroe Aceh Darussalam No. 11/ 2002 tentang Pelaksanaan Syari'at Islam Bidang Aqidah, Ibadah dan Syi'ar Islam, and Qanun No. 12/2004 tentang Kebudayaan Aceb; Qanun Propinsi Nanggroe Aceh Darussalam No. 23/2002 tentang Penyelenggaraan Pendidikan also contain provisions for Islamic education to be "based on the Quran and the Sunna", while also subject to the stated objectives of the Indonesian national educational system. The most dramatic instance of such, however, has been a proposed code of Islamic criminal law known as the Qanun Jinayat. This bill attracted global media attention to its hard-line stance on issues of sexual morality, and in particular for its stipulation of the penalty of execution by stoning for convicted adulterers. While this bill was passed in the last hours of a lame duck session of the provincial legislature in 2009, the governor of Aceh refused to sign the bill, and to this date it remains in effect a dead letter; R. Michael Feener, "Hand, Heart and Handphone: State Shari'a in the Age of the SMS", Contemporary Islam: Dynamics of Muslim Life, vol. 7, no. 1 (2013), p. 18.

${ }^{17}$ Robin Bush, "Peraturan Daerah Syariah di Indonesia: Keganjilan atau Gejala", in Ustad Seleb, Bisnis Moral dan Fatwa Online: Ragam Ekspresi Islam Indonesia Kontemporer, ed. by Greg Fealy and Sally White (Jakarta: Komunitas Bambu, 2012), pp. 175-83.

${ }^{18}$ Qanun No. 11/2012, article 3. 
In addition, discipline of women's bodies is also socialized with banners that appeal for conformity to the Islamic dress. Banners are strategically displayed in particular places where it is possible for the authorities to enforce the code. During my observation in August 2012, there are at least four banner locations in Langsa containing disciplinary messages on women's fashion; these are the Grand Mosque, Muhammadiyah School Complex, Junior High School (SMPN) 9 of Langsa, and the campus of State College for Islamic Studies (STAIN) Zawiyah Cot Kala.

The banners in the Grand Mosque read: (a) Kawasan Wajib Berbusana Islami, Dilarang Memakai Pakaian Ketat [mandatory Islamic dress area, do not wear tight clothes] and (b) Kawasan Wajib Berbusana Islami [mandatory Islamic dress area]. The other banners say: Anda Memasuki Kawasan Wajib Berbusana Islami, Dilarang Membuka Aurat atau Berpakaian Ketat [You are entering a mandatory Islamic dress area. Don not uncover the Aurat or wear tight clothes] (Muhammadiyah Education Complex); Dilarang Masuk! Bagi Yang Tidak Berpakaian Muslim/Sopan [those not wearing proper or Islamic dress are not permitted to enter] (Junior High School, SMPN 9); Anda Memasuki Kawasan Wajib Berbusana Muslim [you are entering a mandatory Islamic dress area] (STAIN Zawiyah).

Most of the banners are displayed at the main entrances of these locations. It implies that the banners dictate who is allowed or not allowed to enter the area. This phenomenon is in line with the concept of panopticism from Foucault. ${ }^{19}$ Panopticon is a kind of tower which is built by the authority to conduct surveillance against the target. ${ }^{20}$ Through a banner's specific instructions to wear a particular dress, women will always feel that they are surveilled by authorities to dress accordingly.

\section{Razia as Disciplinary Instrument over Women's Bodies}

Perhaps, ever since the implementation of shari'a in contemporary Aceh, Wilayatul Hisbah (WH) which is often referred to as Aceh's Shari'a Police, has been getting public attention. When the WH was first establised, it only operated in and arround Banda Aceh. By late 2006, however, more of its branches were established at the district level (kabupaten/kota) across the province. The WH was first created through the enactment of regional regulation No. 5/2000, and futher defined to

${ }^{19}$ Michel Foucault, Discipline \& Punish: The Birth of the Prison (Knopf Doubleday Publishing Group, 2012), p. 195.

${ }^{20}$ Ibid., p. 200. 
'reprimand' (tegur) and 'advise' (nasehat) those caught violating the Shari'a regulations defined by Acehnese Qanun. ${ }^{21}$

I will show how $\mathrm{WH}$ authoritatively conducted razia in Langsa as a strategy to impose body discipline. On a Saturday night, May 2013, the WH carried out a razia around Merdeka Square. That day, the Head of DSI Langsa, accompanied by the WH, patrolled the square using a loud speaker to address the people, telling all unmarried, illegal couples and uncovered women to disperse and return to their homes. They inspected several illegal couples of non-mahram ${ }^{22}$ and women who were not covering their aurat. ${ }^{23}$ In response, I saw that people protested against the razia; and the clash was inevitable. Out of nowhere, one of the hawkers threw stones at a patrol car and swore at the officer. ${ }^{24}$

The behaviours of the residents of Langsa are intensively curbed by these razia. On 1 May 2012, for example, WH came to the central market of Langsa and reminded vendors and tailors not to sell dresses that are contrary to Islamic law. They distributed an instruction letter from the Major of Langsa City stating that the tailors and vendors are prohibited from selling tight dresses, or dresses that show the shape of body. ${ }^{25}$ This is one of WH's routines in the enforcement of shari'a. Over

${ }^{21}$ Feener, "Hand, Heart and Handphone", pp. 20-1.

${ }^{22}$ A person together with an opposite sex friend that is not his/her relative are considered as non-mabram couple. The family relation between two persons is called mabram-related if they cannot legally marry each other.

${ }^{23}$ Aurat is derived from Arabic word which means the body parts that should not be openly display to the public; usually the part that would sexually appeal the opposite sex.

${ }^{24}$ Field note, 5 May 2013. The next day, the local newspaper, Rakyat Aceh, released the headline titled "Regulate Teen Dating, WH Patrol stoned". In the news, Ibrahim Latif, the Head of WH, stated that "the throwing of stones began when WH officers where on a routine patrol for monitoring and enforcement of Islamic law. When crossing the Road at Merdeka Square around 22:30 pm, officers spotted a number of teens and young adults engrossed in dating in dark places of the region. Since the law has been violated, eventually WH ordered the young couples to disperse. "Stones were suddenly thrown at WH officers by a group of youths from the darkness. After throwing the stones at WH, the youths fled"; "Regulate Teen Dating, WH Patrol Stoned", Rakyat Aceh (6 May 2013), pp. 1-2.

${ }^{25} \mathrm{WH}$ appealed to traders to not provide, sell, sew or design fashion opposed to the Islamic law (tight/sexy clothing). Workers, waitresses, dress shops and supermarkets were not strictly implementing the mandatory rule that dress should not be transparent or show any curves of the body. According to Latif, the inspection to central market of Langsa is a follow-up of the Mayor City Instruction No. 2984/450/2012 (dated 26 November 2012) that is addressed to merchants, clothing tailors and store/supermarket 
the past two years, a similar razia is conducted in various places in Langsa almost weekly. The action is often conducted more than once a week. In late August 2012, the DSI Chief Ibrahim Latif told me that within a month, the DSI Langsa had carried out three razia, as they believed it to be one of the strategies to regulate public behaviour in Langsa.

\section{Reasons for Choosing Hidden Resistance}

The hidden transcripts is not a dramatic resistance. At this point, no one fighting for the interests of this subordinate class has claimed to be hero. ${ }^{26}$ We are also not talking about an organized resistance, but rather guerrilla actions that are sporadic, irregular, and enacted individually. Borrowing Scott, "here we are dealing with a fight that was not dramatic", but they are everywhere. ${ }^{27}$

Not everybody considers that the woman entering the mosque in jeans, perfunctorily covering her jeans with a sarong, which she then removes as she leaves (as noted in the introduction), is performing an act of resistance. One may never get a direct response from the woman in relation to her rationale. This could be obtained only if one understood the context behind the phenomenon and agreed that resistance is not merely an act of dramatic attack against the parties opposed. This is about a "symbol of reassertion of the lost power" 28 or what Scott has termed the "weapons of the weak". ${ }^{29}$

Accordingly, the question arises, what do the women fight by revealing their hidden resistance? When analysing the hidden resistance of poor farmers in Kedah, Malaysia, Scott shows that farmers still expect access to work from the dominant elite, and to income and reparations for lost status as a result of the introduction of the double harvest season..$^{30}$ This phenomenon indicates that the participants' hidden transcript is not fully prepared to lose certain benefits due to the attitude of resistance which they did.

chair persons to support the enforcement of Islamic law in Langsa; "Tim Anti Maksiat Sidak ke Toko Pakaian", Serambi (1 May 2013).

${ }^{26}$ Scott, Domination and the Arts of Resistance, p. 112.

${ }^{27}$ Scott, Senjatanya Orang-orangyang Kalah, p. 321.

${ }^{28}$ Merve Kavakci Islam, Headscarf Politics in Turkey: A Postcolonial Reading (New

York: Palgrave Macmillan, 2010), p. 96.

${ }^{29}$ Scott, Senjatanya Orang-orang yang Kalah.

${ }^{30}$ Ibid., p. 321. 
In this section, I will show the reasons subordinate women express their resistance. Although both are in clumps of Acehnese identity, people in Langsa feel that they are in a different hatching place, compared to for example Banda Aceh, Meulaboh, and Lhokseumawe. However, it is undeniable that the political and social conditions, culture, multicultural character and geography make Langsa, in some ways different from other regions in Aceh. On the one hand, the women of Langsa construct their identities as Muslims. At the same time, they construct their identity through dress, which at some level is different from other places in Aceh.

Being fashionable is an obsession for many women. The motive behind the hidden resistance, besides as an expression of understanding of religious doctrine, is also based on a desire to keep up with fashion which is changing with the times. Thus, when a government official proposes a return to uniformity as a way of getting rid of all these differences, the official faces opposition from those who campaign the right to follow the fashion of the day. ${ }^{31}$ Fashion has become an important vehicle for expressing resistance..$^{32}$ Borrowing the framework of Saba Mahmood, a reformulation process of the piety conception in dressing is a strategy through which Langsa women express their Islamic subjectivities. ${ }^{33}$

\section{E. Hidden Transcripts and Everyday Forms of Resistance}

\section{Redefining Piety}

The concept of piety has become the source of conflict between subordinate and superordinate classes. Generally, Islamic religious elite view the practice of veiling as of 'primary and pure meaning', based on Islamic principles with reference to the Quran, the essential and divine source of Islamic thought, and the Sunnah, the secondary and worldly source generated from the commentaries of the prophet Muhammad. ${ }^{34}$ They suggest the necessity of covering the female body to conceal it from

${ }^{31}$ Joan W. Scott, The Politics of the Veil (Princeton: Princeton University Press, 2007), p. 112.

${ }^{32}$ Homa Hoodfar, "More Than Clothing: Veiling as an Adaptive Strategy", in The Muslim Veil in North America: Issues and Debates, ed. by Sajida Sultana Alvi, Homa Hoodfar, and Sheila McDonough (Toronto: Women 's Press, 2003), p. 10.

${ }^{33}$ Compare: Saba Mahmoud, Politics of Piety: The Islamic Revival and the Feminist Subject (Princeton: Princeton University Press, 2005), p. 1.

${ }^{34}$ Barış K1lıçbay and Mutlu Binark, "Consumer Culture, Islam and the Politics of Lifestyle: Fashion for Veiling in Contemporary Turkey", European Journal of Communication, vol. 17, no. 4 (2002), p. 497. 
the male gaze, as a sign of adherence to the Islamic faith and belief. ${ }^{35}$ In short, this moral issue is one of the ultimate reasons Muslim women wear the veil. ${ }^{36}$

However, the general view of the religious elite in authority in Langsa, who claim that it is necessary to express piety through dress, is not well accepted by the majority of women. Ida (22 years old) and Aida (24 years old), for example, said that morality and piety needed to be shown on the substantive dimension rather than merely through the symbolic one. Wearing a loose head cloth is not fully agreed on as a symbol of piety and morality. As said by Susan J. Rasmussen, in many Muslim communities veiling is not solely a religious symbol, but is also considered an aspect of women's fashionable dress more generally. ${ }^{37}$

Ayun (23 years old) said "God does not look at a person based on the shape of the body, but rather based on their hearts". ${ }^{38}$ This is a hadith narrated by Imam Muslim that is often used by muslims to say that Islam supports egalitarianism. However, this hadith is used by Ayun to justify her opinion that wearing the veil or leggings are not the right variables with which to measure piety. Ida agrees that piety is always associated with the appearance and dressing style. Hijab is just a matter of fashion rather than an expression of a woman's piety. It could be that a "woman wears the headscarf and loose-fitting clothes, but behaves against Islamic law" ${ }^{39}$ Every day, Ida wears the hijab, but she admitted that the veil is occasionally opened while in public.

The thoughts above show that there are differences in perspectives between the religious elite and ordinary women, particularly in defining women's piety. Religious elites view wearing Islamic dress as a reflection of one's piety, while the latter essentially reject the view, and empirically

${ }^{35}$ Fadwa El Guindi, Veil: Modesty, Privacy and Resistance (Oxford: Berg, 1999); Fadwa El Guindi, "Veiling Resistance", Fashion Theory: The Journal of Dress, Body \& Culture, vol. 3, no. 1 (1999), pp. 51-80; Zainah Anwar, Islamic Revivalism in Malaysia: Dakwah among the Students (Pelanduk Publications, 1987); Sarah A. Tobin, "Everyday Piety: Negotiating Islam and the Economy in Amman, Jordan", Ph.D. Dissertation (Boston University, 2011), pp. 223-80.

${ }^{36}$ Dian Maya Safitri, "What Went Wrong with the Veil? A Comparative Analysis of the Discourse of the Veil in France, Iran, and Indonesia", Al-Jami'ah: Journal of Islamic Studies, vol. 48, no. 1 (2010), p. 86, http://journal.aljamiah.org/index.php/AJ/ rt/metadata/23/0, accessed 9 Oct 2014.

${ }^{37}$ Susan J. Rasmussen, "Re-casting the Veil: Situated Meanings of Covering", Culture \& Psychology, vol. 19, no. 2 (2013), p. 239.

${ }^{38}$ Interview (29 Aug 2012).

${ }^{39}$ Interview (28 Aug 2012). 
support their views with daily experience of women who naturally live in accordance with the fashion of the times. Baris Kiliçbay and Mutlu Binark termed this a shift in the meaning of clothes from just a symbol of piety to the culture of consumption.

We claim that a new meaning could be attributed to the practice of veiling that is the articulation of religious practice to the consumption culture... The rise of what could be called a 'fashion for veiling' is a result of this articulation process. We argue that the practice of veiling is inseparable from consumption, commodity, even pleasure pattern, and is stimulated by global and local trends of the market economy. ${ }^{40}$

Ayun and Ida, in defining the relationship between piety and women's clothing, are always subjected as women to the background of the social and fashion context of their time. The conception of piety is greatly influenced by the social context of the time in which piety is defined. Resistance against mainstream conceptions of piety and clothing emerges as the desire of individuals to be a subject that defines, not one that is defined. This argument is parallel to the research conducted by Suzanne Brenner about muslim women wearing the veil in Java. She reveals that the veil serves not merely enshrinement of religious piety, but an embodiment identity around the world, and the reconstruction of societies via individual and communal self-discipline. ${ }^{41}$

\section{Rationalizing Reasons for Choice of Dress}

The arguments of the subordinate classes on dress choices are actually very comprehensive. They build the most striking argument with a particular term justifying their actions. When Aida says that she prefers to wear pants rather than a skirt on a long journey, she was actually criticizing authority on campus that obliged women to wear skirts. For Aida, the skirt is only suitable in certain conditions and, therefore, cannot be claimed as the only type of Islamic dress which is allowed. However, when the college put up a banner demarcating a "Mandatory Islamic Dress Area", which meant that the Islamic dress code for woman was wearing a skirt, for Aida, the logic behind the rule was not only inappropriate but also a confusion of thought. ${ }^{42}$

${ }^{40}$ Kiliçbay and Binark, "Consumer Culture, Islam and the Politics of Lifestyle: Fashion for Veiling in Contemporary Turkey", p. 49.

${ }^{41}$ Suzanne Brenner, "Reconstructing Self and Society: Javanese Muslim Women and 'The Veil”", American Ethnologist, vol. 23, no. 4 (1996), pp. 673-97.

${ }^{42}$ Interview (29 Aug 2012). 
Aida proposed the scenario of a woman riding a motorcycle from Langsa to Banda Aceh. If Islam forbade women to wear pants and says that wearing the skirt is seen as more Islamic, we must consider which is safer when traveling by motorcycle for a long journey that take eight hours. ${ }^{43}$ For Aida, wearing the skirt would be more comfortable than wearing the pants only in the condition that the traveller sat in a private car, instead of on a motorcycle. As she explained, in our social context only a few people drive cars, while Islam has not been sent only for those few. For a mother who is traveling on a motorcycle while carrying a baby, wearing a skirt would be more dangerous than wearing pants. ${ }^{44}$

Atun (38 years old), a Langsa resident who works as a janitor, shared a similar view. She said that she could not understand the opinion that wearing a sarong is more Islamic than wearing jeans. If the WH and DSI claimed that wearing a sarong, as commonly worn by women in villages, is more Islamic than wearing a pair of leggings or jeans with a long shirt down to the knees, which type of dress actually has more potential to reveal the shape of female hips? ${ }^{45}$ In my opinion, Atun's argument is definitely right because the general opinion in Aceh said that women should be wearing sarong when traveling.

Atun chose to criticize general opinion about associating the sarong with the expression of female piety. The argument proposed by Atun, in my opinion, is that the logical reason for wearing Islamic dress was intended to protect women from unwanted sexual advances and innuendo or sexual abuse. Which type of dress arouses more sexual attraction between sarong and pant? Atun gave her critical opinion about the way women wrap their sarongs, "Women who wear sarongs actually reveal more of the overall shape of her hips, tempting the male sexual desire". As the janitor who has to leave the house early in the morning, wearing pants can be a more Islamic than wearing sarong. ${ }^{46}$

It should be noted that sometimes the angle from which the subordinate class views is not similar to that of superordinate class does. Debates on whether to wear sarongs or pants, are a way for women like Atun and Aida to rationalize the reasons they choose to wear the type of dress that they wear every day. Their views differ significantly to those of the DSI Chairman, Ibrahim Latif.

\footnotetext{
${ }^{43}$ Interview (29 Aug 2012).

${ }^{44}$ Interview (29 Aug 2012).

${ }^{45}$ Interview (29 Aug 2012).

${ }^{46}$ Interview (29 Aug 2012). 
Some women wear trousers and a headscarf, a scarf that covers the head only. They also infiltrated their scarf into blouse, which doesn't cover their breast. In their mind, this meets the requirements of Islamic dress code. In fact, it does not meet the standards stipulated by Qanun No. 11/2002. Qanun 11/2002 refers to the verses of Quran, surah alAhzab: 59. Well, at least, they still want to wear the veil. Although it does not meet the 100 per cent standard, that is okay... never mind. There are also women who wear tight pants, wear tight clothes, and do not wear the veil. It is sexy. Certainly they would be stopped in the razia. We won't let them go until their parents come with a hijab for them to wear. Then we ask them to make a statement before their parents. ${ }^{47}$

The verbal fight between the dominating and the dominated takes place and each group always produces discourse to reinforce each argument. Exaggerating the words, expressing particular events with hyperbole becomes a ritual of the so called 'war' between the superordinate and subordinate classes. Aida's presupposition about women riding a motorcycle to travel eight hours is a rare case, but it is chosen as the base argument to win the verbal war. For Latif, a male, the ideal is that women wear sarongs and veils, while a woman such as Atun argues that women wearing sarongs invite more sexual attention. Clearly, the verbal war by nature often takes the perspective which points out the weakness of the opponent's argument.

\section{Gossip and Rumors: Routine Resistance in Routine Repression}

The relationship between the dominant elite and the subordinate classes in Langsa is one of intrigue --characterized by rivalry against each other, efforts to defame each other, and attempts to delegitimize authority. These efforts are either based on reliable and truthful stories, gossip and heresy, or perhaps irresponsible accusations. Nevertheless, do not imagine that this is a battle that is fought and defended in the public realm as in the drama of a presidential candidate overcoming and defeating his political opponents. This is a story that involves a third party as a loyal listener, while the fighters, the superordinate and the subordinate classes, do not fight face to face. ${ }^{48}$ Gossip is the opposite of

${ }^{47}$ Ibrahim Latif, Head of Department of Islamic Law Langsa, interview (28 Aug 2012).

${ }^{48}$ Niko Besnier, Gossip and the Everyday Production of Politics (University of Hawaii Press, 2009), p. 191. Gossip as an expression of resistance from sub-ordinate group is sharply discussed by Besnier, said that gossip is one strategy subordinate groups employ 
"speaking properly", which is the ideal way by which conflict should be managed. ${ }^{49}$ But gossip itself is actually the sophisticated art of hidden transcripts which is launched by subordinate groups.

Gossip, by definition, is the story of the backstage in social life. ${ }^{50}$ Scott revealed that gossip is a story told about a third party who is not present; once it is proposed, it can be anonymous with no original story but many distributors. Although gossip does not necessarily respect people, with malicious gossip a reflection of the broader normative order in which it operates. Behind every piece of gossip is not just a word, there is an implied statement about a norm that has been violated. Indeed, only a violation of behaviour makes a valuable and interesting event to be gossiped or talked about. ${ }^{51}$

The character of gossip that distinguishes it from rumor is that gossip consists typically of stories that are designated to ruin the reputation of some identifiable person or persons. A person's reputation can be damaged by stories about his tightfistedness, his insulting words, his cheating, or his clothing only if the public among whom such tales circulate have shared standards of generosity, polite speech, honesty, and appropriate dress. Without an accepted normative standard from which degrees of deviation may be estimated, the notion of gossip would make no sense whatever. Gossip, in turn, reinforces these normative standards by invoking them and by teaching anyone who gossips precisely what kinds of conduct are likely to be mocked or despised. ${ }^{52}$

Some cases need to be exemplified on the resistance through gossip. On the night of 1 September 2012, I met with Yanto, my neighbour, at the DSI office. He went to the DSI office to pick up a family member caught in a razia for khalwat and dress code about two hours earlier. When I asked Yanto's opinion about the razia conducted by WH Chief of DSI, with a cynical tone Yanto said that nowadays the Mayor has to arrange the structural formation of the DSI after he is elected and sworn in by the Governor of Aceh. "The head of DSI must show off in order to maintain his post," he whispered to me. ${ }^{53}$ Two days earlier, when I was in enacting their political will in everyday life.

${ }^{49}$ Ibid., p. 96.

${ }^{50}$ Tuulikki Pietila, Gossip, Markets, and Gender: How Dialogue Constructs Moral Value in Post-Socialist Kilimanjaro (Madison: University of Wisconsin Press, 2007), p. 7.

${ }^{51}$ Scott, Senjatanya Orang-orang yang Kalah, p. 372.

${ }^{52}$ Scott, Domination and the Arts of Resistance, pp. 142-3.

${ }^{53}$ Yanto's commentary about a raid that conducted by DSI at night is a piece of his assessment for the implementation of raids. Yanto statement is one example of Al-Jāmi‘ah, Vol. 52, No. 1, 2014 M/1435 H 
in a cafe at Merdeka Square, I listened to a group of women chatting, one of them wearing a veil. They were chatting about their disapproval of the rise in the number of veil razia. On my way home, I saw women who were not veiled take a veil from their bag and put it on. ${ }^{54}$ It is highly probably they did this in anticipation of a razia.

Gossip as a form of resistance also appeared around the case of a girl who was raped by three WH officers. During my field research in October 2010 in 30 villages in Langsa, my respondents always associated my questions related to the implementation of Islamic law with the rape incident that took place in January 2010. My questions seem had triggered them to reveal many things that actually had been often recycled in any conversation in a coffee shop or women's gossip sites. The personalities of each WH and of DSI members have become open gossip among locals. ${ }^{55}$

The extent to which there is any truth to most gossip or rumour cannot be verified. However, factually, gossip does not emphasize the good value or the validity of a story, but rather it can be a means to express resistance without any evidence. Gossip is expressed as a form resistance against the enforcement of Islamic law by the authority. According to Scott, gossip usually has a hidden agenda. ${ }^{56}$ Gossip can destroy one's reputation. Through gossip a regulation that is commonly accepted will be confirmed and promoted immediately. While, the regulation that is less acceptable will be ruined by nationwide gossip. ${ }^{57}$

how the seeds of gossip reproduced. DSI Chief, of course, will never justify Yanto's assessment. But, it is certain that a similar assessment will quickly flow from one mouth to another; interview (1 Sep 2012).

${ }^{54}$ Field note (29 Aug 2012).

${ }^{55}$ Employment recruitment processes have become the topic of local gossip. Rena (26), a member of the WH, said that people are talking about the reason why Leni, a 23 year old local singer, can be accepted as a member of the WH. Some of them hoped Leni would change her appearance and demeanour after becoming a member of the WH but there has been no change in the four years she has been employed. In Seulalah Baru, Langsa Lama, gossip about a WH's involvement in a rape circulated quickly in the community. Wanda (male pseudonym), a WH who is rumoured to have been caught by locals being sexually exploiting a woman, settled the issue by customary law and then married the woman. The gossip surrounding Leni and Wanda did not stop there. People talked about the indecision of WH leadership in allowing Wanda to remain employed despite that he has defamed the institution. The story of Leni inspired people to produce more gossip about WH. There are many stories about the recruitment of WH members who are beyond normality and propriety. It always comes down to who is behind the person and how much money is spent for their acceptance into the WH.

${ }^{56}$ Scott, Senjatanya Orang-orangyang Kalah, p. 373.

${ }^{57}$ Ibid.; Besnier, Gossip, p. 120. 
For the people of Langsa, the constellation of information circulating as gossip occupies an eminent position because the point of gossip is to delegitimize the social status of the assaulted party. Gossip has different implications for different people, and different consequences for the form that gossip takes. ${ }^{58}$ According to Niko Besnier, the social consequences of gossip may include ridicule, ostracism, or even death. ${ }^{59}$ Anyone who becomes the subject of rumour is usually at the same time furthest from the line of public normality or at least on the verge of accepted standards of public normality. A person included on the list of gossip subjects is at the same time placed outside the zone of public order.

\section{Traces of Resistance in Online Media}

Complementary to Scott, who limited the analysis of hidden transcripts to the form of resistance in social interaction which is real and immediate, I would add the phenomenon of hidden transcripts expressed through online media. Scott's research did not include to the forms of hidden resistance enacted through online media since the book was written before the internet had grown into the global media and information tool it has become today. However, social change and technological revolution provide the channels for the articulation of resistance by subordinate groups against the dominant elite. Online media become a space of articulation channel that probably never imagined by people in Sedaka, Kedah, where Scott done his study.

Today, online media has become one of the effective channels in articulating the resistance movement. ${ }^{60}$ Parallel to the focus issue, I will show some cases of the expression of hidden resistance in online media. Today, for instance, by browsing the phrase "Putri Gantung Diri di Langsa", one will get various reports about a girl who committed suicide after being caught in a razia conducted by WH and DSI in early September 2012. Putri Erliana (17 years), depressed, was reported to have hanged herself because she was unable to bear the humiliation of

\footnotetext{
${ }^{58}$ Besnier, Gossip, p. 98.

${ }^{59}$ Ibid., p. 17.
}

${ }^{60}$ Arthur Edwards, “The Dutch Women's Movement Online: Internet and the Organizational Infrastructure of a Social Movement", in Cyberprotest: New Media, Citizens, and Social Movements, ed. by Wim B.H.J. van de Donk et al. (Psychology Press, 2004), p. 175; Abigail Schoneboom, "Diary of a Working Boy: Creative Resistance among Anonymous Workbloggers", Ethnography, vol. 8, no. 4 (2007), pp. 403-23; Merlyna Lim, "The Internet and Political Activism in Indonesia", Ph.D. Dissertation (the University of Twente, 2011). 
being accused of being a prostitute by DSI and WH. The news of the death of Putri invited protests and accusations of alleged violations of human rights conducted by WH and DSI. ${ }^{61}$ The following discussion traces the forms of hidden resistance expressed through online media. A online reader's comment on news of the death of Putri is interesting: Eh... om WH, jangan sama masyarakat aja garang, sama pejabat kalian melempem macam kerupuk masuk... ini Langsa om, Kota yang menerima kebebasan \& keterbukaan selama tidak melanggar hukum... kalau pakaian muslim cuma dipakai untuk menutupi kejahatan untuk apa???? [Eh ... om WH, not to usual people you are fierce, but to officials you are the same kind of sluggish crackers... This is Langsa, the city that tolerates freedom and openness as long as it does not break the law ... If Muslim clothing is just used to cover up the crime then what is the point????] ${ }^{62}$

The comment from someone who called Bujang Langsa shows the cynical comments of a public against the razia conducted by DSI and WH. Bujang Langsa condemned the razia as being only subjected on the ordinary people, but not on the elite who violate the dress code, but who are untouchable. Similar comments can be read as follows, posted by Saya Pejabat:

Makanya contoh pejabat di langsa... mau eh..ob ke medan cari lonte ... jangan disini kena tangkap WH [Therefore, you must copy the conduct of officials in Langsa ... want eh ... oh. go to Medan looking for a whore... do not do it here for you could be arrested by $\mathrm{WH}]{ }^{63}$

The post from Saya Pejabat is a response to other comments. It should be mentioned that, about four days before the Putri Erliana was caught, DSI also conducted khalwat and tight dress razia at night on Langsa's Ring Road. At least nine unmarried couples were arrested and brought to the DSI office. This incident made the headlines in most local media. The construction of the reports is quite impressive, teens were targeted as doing something immoral or that leads to immoral acts despite the fact that they were merely driving along the road.

The comments posted by Saya Pejabat suggest that the behaviour of teenagers on Langsa's Ring Road is nothing in comparison to the

${ }^{61}$ "Kasatpol WH Aceh: Anak Itu Binasa Karena Ulah Dia Sendiri”, The Globe Journal, http:/ / theglobejournal.com/Hukum/kasatpol-wh-aceh-anak-itu-binasa-karenaulah-dia-sendiri/\%20index.php, accessed 16 Sep 2012.

62 "Sembilan Pasangan Kekasih Diciduk WH", Tribunnews.com (16 Sep 2012), http://aceh.tribunnews.com/2012/09/03/sembilan-pasangan-kekasih-diciduk-wh.

${ }^{63}$ Ibid. 
behaviour of (partially) officials in Langsa. The difference is that the officials will go to Medan if they wanted to hire a prostitute, thus, their behaviours are free from legal sanction and from razia by WH. The expression above is similar to the previous one; it describes social cynicism against discriminative acts of body disciplining.

Both comments above use the same topic to express protest against the disciplining of women's bodies: only ordinary people are subjected to razia. Contextually, these comments are very convincing. Discrimination and inequality in the enforcement of Islamic law in Langsa have become a problem since about a year ago when the public in Langsa were shocked by the news of a razia involving a local legislator who stayed overnight in a girl's rented house. However, people can express their anger online but the plot is predictable, double standards exist: the legislator was freed from all charges, including shari'a law. ${ }^{64}$

Hidden resistance through online media takes different forms, including innuendo, gossip, insult, and rumour. As Scott said, the subordinate class actually have more material stock upon which to express sarcasm, nagging, or even invectives than the dominant elite class. ${ }^{65}$ Sometimes, a satire will be upgraded to become rumour. The weak or less powerful will flee immediately when they realize the risks for the expression that they wrote through mass media. Usually, the subordinate class is more aware of the risks that they may face so they disguise their identities. Pseudonym as a protection strategy is very useful for allowing anonymity and a greater degree of freedom of expression for those critical.

\section{Compliance Localization: Part Timer Tight Dress}

The tactics of the subordinate class in negotiating the power of and pressure from the dominant elite always requires creativity that goes far beyond normal standards. As a result, according to Erik M. Heen,

${ }^{64}$ Improper action or adultery involving legislators in two neighbouring districts in Langsa, namely Aceh Timur and Aceh Tamiang, has become gossip in a coffee shop and the local media. Despite this, none of the accused were charged under the law, especially shari'a law, despite the fact that there was public pressure to disable their party. Since the Mahkamah Syariah had sentenced perpetrators of similar 'crimes' in the past to a public whipping, the public were hoping the legislature members would get a similar punishment. It is not surprising that when the public of Langsa heard or read of the raids on khalwat conducted by WH and DSI, they criticised whether the DSI and WH had the courage to punish the officials who violated the Qanun of khalwat.

${ }^{65}$ Scott, Domination and the Arts of Resistance, p. 131. 
hidden resistance does not become just a specific cultural product, but also produce a new culture. ${ }^{66}$ When STAIN Zawiyah Cot Kala obliged students to wear skirts on campus, the students created a sub-culture by wearing tight pants or dresses off campus. They produced their own culture which is distinct from the culture produced by top down dominance relations in campus. ${ }^{67}$

The embodiment of a sub-culture and the phenomenon of localization of obedience also occurs at Samudra University (Unsam), a state university in Langsa. Samudra University of Langsa does not require all female students to wear skirts, except those in the Faculty of Education (FKIP). Consequently, beyond the need to follow course and administrative requirements, female students often choose to dress as they desire: to look fashionable in jeans or leggings. Therefore, in that campus, new habits are appearing, female students replace skirts with pants in the bathroom after class. The basic principle of the mandatory wearing of skirts is adhered to only when the class period is going on. Such disciplining of the body is just obeyed in class, while outside of class time students were no longer bound by the rules. ${ }^{68}$

The phenomenon reported at the beginning of this article in which women enter the Grand Mosque wrapping their lower bodies in a sarong to cover their tight pants shows how women localize their obedience. They never said that they rejected the imposition of disciplinary body

${ }^{66}$ Erik M. Heen, "The Role of Symbolic Inversion in Utopian Discourse: Apocalyptic Reversal in Paul and in the Festival of the Saturnalia/Kronia", in Hidden Transcripts and the Arts of Resistance: Applying the Work of James C. Scott to Jesus and Paul, ed. by Richard A. Horsley (Atlanta, GA: Society of Biblical Literature, 2004), p. 127.

${ }^{67}$ According to Aida, "If we must wear the veil on campus, and the convention is such, we do not mind. But most of the female students think that if they leave campus it is up to them how they dress ... the obligation to wear the veil does not matter if it is on campus. But out of campus, it is not the lecturer's business anymore. It is my business. Most of the students were of this opinion. The general sentiment was if I want to wear shorts or pants, it is outside of the rules and if I am caught by lecturers outside the campus, it will embarrass as well. It is all because of fashion. I have observed that women who wear veil because of her consciousness are small in percentage. It can be counted"; interview (29 Aug 2012).

${ }^{68}$ In an interview, Aida says: "In Samudra University (Unsam), Langsa, students of FKIP must wear skirts because they are prospective teachers. In other subjects, there are certain professors who require their students to wear a skirt. In the Faculty of Law, there is also a lecturer who requires female students to wear a skirt in class. So, from their homes students wear a skirt, but underneath it she wears jeans or brings the jeans in her bag. And then, after she has finished classes, she changes into the pants in the bathroom.” Interview (29 Aug 2012). 
through regulations written up at the mosque, but they prefer to localize the implementation of the rules. In the Grand Mosque, women realized that their dress may be less in accordance with the specifications set by the mosque, but they localize the imposition blindly by simply wearing sarong when entering the mosque. Outside the mosque, the regulation is not enforceable. ${ }^{69}$

The capacities of this subordinate class in building relationships with the dominant elite class are their awareness about the importance of the art of pretending that is so necessary in life. ${ }^{70}$ Aida and Ayun are very conscious of the need to dress according to specified rules when they are in the campus area. It is necessary to obey as a way to stay safe. Therefore, Aida and Ayun carefully and thoroughly maintain their appearances: how they must look while they are on campus and how they must look off campus. Creating imaginary boundaries is one of the most creative ideas that emerged from the contemplation of those with less power.

Accordingly, the real story of women's resistance to the disciplining of the female body is seen in their daily lives outside the place where the rule's control is effective. Conforming, they wear tight dress only parttime. This is the negotiation that they offer, even though it is a bid that is only partially tolerated by the dominant elite. Mr. Ibrahim Latif said that, if we razia all the tightly dressed women, it would be a major hassles. ${ }^{71}$ Similar to the study of Asef Bayat of the subordinate community movement in Iran, ${ }^{72}$ in Langsa the subordinate class (predominantly women) has chosen various strategies to effectively achieve their goal of resistance.

\section{F. Concluding Remarks}

Shari'a-based disciplining of the female body has triggered

${ }^{69}$ Pretended obedience phenomenon and localization of obedience was seen on 19 Sep 2012 when the DSI conducted a raid on tight clothes in Merdeka Square. A teenager, Noni (16) was being reprimanded for wearing tight clothes and not being veiled. Mr. Latif, the Head of DSI, asked Noni to sign a letter stating that she will not repeat her actions. He also asked a family member or friend of her to deliver the veil. A friend then dropped the veil off. After putting on the veil, Mr. Latif released her. However, about ten meters away from the location of the raid, she stopped her motorcycle and took off the veil. Mr. Latif could only shake his head.

${ }^{70}$ Scott, Senjatanya Orang-orang yang Kalah, p. 376.

${ }^{71}$ Ibrahim Latif, interview (28 Aug 2012).

${ }^{72}$ Asef Bayat, Street Politics: Poor People's Movements in Iran (Columbia University Press, 1997). 
resistance from some women in Langsa, although their resistance is often expressed secretly (hidden transcripts). Hidden resistance may take various forms, such as redefining the relationship between piety and women's dress; rationalizing their choice of clothing; utilizing gossip, rumour, innuendo, and even invective against superordinate group; utilizing online media to express anonymous resistance, and pretending to obey the regulation and localizing the obedience.

The disciplining of women's bodies through dominance and repressive approaches instead of triggering the formation of public morality as one might imagine triggers a minor image of the implementation of Islamic law. Instead of encouraging awareness about the implementation of shari'a according to Islamic law, it evokes the dominance of resistance. Women resistance is shown through the inclination towards the domination of certain perspectives related to female body discipline.

Last but not least, I would like to remind the dominant elite, both government officials such as WH and Department of Islamic Law, as well as other institutions to select certain approaches that are more egalitarian, democratic and appreciative of diversity in raising public awareness to implement shari'a in Langsa. The imposition of one particular interpretation in defining morality in the public sphere will not only hinder the realization of the expected results, but also will be counter-productive to the principles of Islam. 


\section{BIBLIOGRAPHY}

Anagol, Padma, "From the Symbolic to the Open: Women's Resistance in Colonial Maharashtra", in Behind the Veil: Resistance, Women, and the Everyday in Colonial South Asia, ed. by Ghosh Anindita, Permanent Black, 2007, pp. 21-57.

Ansor, Muhammad, Muhammad Abu Bakar, and Zubir, Religiusitas dan Sikap atas Pelaksanaan Syariat Islam di Langsa, Research, Aceh: STAIN Zawiyah, 2010.

Anwar, Zainah, Islamic Revivalism in Malaysia: Dakwah among the Students, Pelanduk Publications, 1987.

Barter, Shane Joshua, "Ulama, the State, \& War: Community Islamic Leaders in the Aceh Conflict", Contemporary Islam: Dynamics of Muslim Life, vol. 5, no. 1, 2011, pp. 19-36 [doi: 10.1007/s11562-010-0141-8].

Bayat, Asef, Street Politics: Poor People's Movements in Iran, New York: Columbia University Press, 1997.

Besnier, Niko, Gossip and the Everyday Production of Politics, University of Hawaii Press, 2009.

Brenner, Suzanne, "Reconstructing Self and Society: Javanese Muslim Women and 'The Veil"', American Ethnologist, vol. 23, no. 4, 1996, pp. 673-97 [doi: 10.1525/ae.1996.23.4.02a00010].

Bush, Robin, "Peraturan Daerah Syariah di Indonesia: Keganjilan atau Gejala", in Ustad Seleb, Bisnis Moral dan Fatwa Online: Ragam Ekspresi Islam Indonesia Kontemporer, ed. by Greg Fealy and Sally White, Jakarta: Komunitas Bambu, 2012, pp. 175-83.

Edwards, Arthur, “The Dutch Women's Movement Online: Internet and the Organizational Infrastructure of a Social Movement", in Cyberprotest: New Media, Citizens, and Social Movements, ed. by Wim B.H.J. van de Donk et al., Psychology Press, 2004.

El Guindi, Fadwa, Veil: Modesty, Privacy and Resistance, Oxford: Berg, 1999.

----, "Veiling Resistance", Fashion Theory: The Journal of Dress, Body \& Culture, vol. 3, no. 1, 1999, pp. 51-80 [doi: 10.2752/136270499779165626].

Feener, R. Michael, "Hand, Heart and Handphone: State Shari'a in the Age of the SMS", Contemporary Islam: Dynamics of Muslim Life, vol. 7, no. 1, 2013, pp. 15-32 [doi: 10.1007/s11562-013-0244-0].

Foucault, Michel, Discipline \& Punish: The Birth of the Prison, Knopf 
Doubleday Publishing Group, 2012.

Heen, Erik M., "The Role of Symbolic Inversion in Utopian Discourse: Apocalyptic Reversal in Paul and in the Festival of the Saturnalia/ Kronia", in Hidden Transcripts and the Arts of Resistance: Applying the Work of James C. Scott to Jesus and Paul, ed. by Richard A. Horsley, Atlanta, GA: Society of Biblical Literature, 2004.

Hoodfar, Homa, "More Than Clothing: Veiling as an Adaptive Strategy", in The Muslim Veil in North America: Issues and Debates, ed. by Sajida Sultana Alvi, Homa Hoodfar, and Sheila McDonough, Toronto: Women 's Press, 2003.

Idria, Reza, Cultural Resistance to Shariatism in Aceh, Final, Jakarta: Islam Research Programm, 2013, http://media.leidenuniv.nl/legacy/ irpfinal2013(2).pdf.

"Kasatpol WH Aceh: Anak Itu Binasa Karena Ulah Dia Sendiri", The Globe Journal, http://theglobejournal.com/Hukum/kasatpolwh-aceh-anak-itu-binasa-karena-ulah-dia-sendiri/\%20index.php, accessed 16 Sep 2012.

Katrak, Ketu H., Politics of the Female Body: Postcolonial Women Writers of the Third World, Rutgers University Press, 2006.

Kavakci Islam, Merve, Headscarf Politics in Turkey: A Postcolonial Reading, New York: Palgrave Macmillan, 2010.

Kıllıcbay, Barış and Mutlu Binark, "Consumer Culture, Islam and the Politics of Lifestyle: Fashion for Veiling in Contemporary Turkey", European Journal of Communication, vol. 17, no. 4, 2002, pp. 495-511 [doi: 10.1177/02673231020170040601].

Lim, Merlyna, "The Internet and Political Activism in Indonesia", Ph.D. Dissertation, the University of Twente, 2011.

Mahmoud, Saba, Politics of Piety: The Islamic Revival and the Feminist Subject, Princeton: Princeton University Press, 2005.

Milallos, Ma. Theresa R., "Muslim Veil as Politics: Political Autonomy, Women and Syariah Islam in Aceh", Contemporary Islam: Dynamics of Muslim Life, vol. 1, no. 3, 2007, pp. 289-301 [doi: 10.1007/s11562007-0028-5].

Pietila, Tuulikki, Gossip, Markets, and Gender: How Dialogue Constructs Moral Value in Post-Socialist Kilimanjaro, Madison: University of Wisconsin Press, 2007. 
Rasmussen, Susan J., "Re-casting the Veil: Situated Meanings of Covering", Culture \& Psychology, vol. 19, no. 2, 2013, pp. 237-58 [doi: 10.1177/1354067X13478989].

Safitri, Dian Maya, "What Went Wrong with the Veil? A Comparative Analysis of the Discourse of the Veil in France, Iran, and Indonesia", Al-Jami'ah:Journal of Islamic Studies, vol. 48, no. 1, 2010 [doi: 10.14421/ ajis.2010.481.81-100].

Salim, Arskal, Challenging the Secular State: The Islamization of Law in Modern Indonesia, University of Hawaii Press, 2008.

Schoneboom, Abigail, "Diary of a Working Boy: Creative Resistance among Anonymous Workbloggers", Ethnography, vol. 8, no. 4, 2007, pp. 403-23 [doi: 10.1177/1466138107083559].

Scott, James C., "Resistance without Protest and without Organization: Peasant Opposition to the Islamic Zakat and the Christian Tithe", Comparative Studies in Society and History, vol. 29, no. 03, 1987, pp. 417-52 [doi: 10.1017/S0010417500014663].

----, Domination and the Arts of Resistance: Hidden Transcripts, London: Yale University Press, 1990.

----, Senjatanya Orang-orangyang Kalah: Bentuk-bentuk Perlawanan Sehari-hari Kaum Tani, trans. by A. Rahman Zainuddin, Sayogyo, and Mien Joebhaar, Yayasan Obor Indonesia, 2000.

Scott, Joan W., The Politics of the Veil, Princeton: Princeton University Press, 2007.

"Sembilan Pasangan Kekasih Diciduk WH”, Tribunnews.com, 16 Sep 2012, http:/ / aceh.tribunnews.com/2012/09/03/sembilan-pasangankekasih-diciduk-wh.

Tobin, Sarah A., "Everyday Piety: Negotiating Islam and the Economy in Amman, Jordan”, Ph.D. Dissertation, Boston University, 2011. 